\title{
Representative Bureaucracy: A typology of normative institutional strategies for the representation of women
}

\section{Introduction}

There remain persistent low levels of female representation in political and public life. Despite the attempts to address female under-representation from the 1970s through equal opportunities, anti-discrimination and affirmative action policies and programmes, the outcomes have been rather modest. This slow progress across public sector organisations has been commented upon by various scholars (e.g. Hale, 1996; Stetson \& Mazur, 1995). Change has occurred but has been incremental at best; women are still under-represented in positions of administrative and political authority in state bureaucracies (see Gieryez, 1999; Kerr, Miller \& Reid, 2002; Meier \& Wilkins, 2002). Although it is often in the policy domains of education, health and social care where women are found, which represents horizontal occupational gender segregation. We argue in this paper that public bureaucracies are responsible for the formulation and implementation of equality policies, yet within these organisations there is vertical and horizontal occupational gender segregation. We therefore suggest a multifaceted approach to addressing the under-representation of women through implementing strategies which are cognizant of the passive and active representation of women in public bureaucracies. Thus, the first section of this paper reviews representative bureaucracy theory to provide a conceptual framework and the development of a typology in the latter sections of the paper. The second section of the paper provides a review of strategies to improve representation of women in political and public life. Finally, the paper provides a typology of representative bureaucracy concluding with suggested strategies for improving the representation of women in public bureaucracies.

\section{Gendered Bureaucracies}

Bureaucracies are not neutral organisational phenomena, but are consistent with relationships present in society. The social construction of gender relations exists within organisations and bureaucracies, invariably based on power relations. According to Nicolson (1996) both gender relations and organisational dynamics are about the achievement and maintenance of power. Furthermore, the ability to influence and control human and material resources exists in social, organisational and other relational contexts where power and subordination are inseparable (ibid). Similarly Savage and Witz (1992), in their comprehensive study and review of gender and bureaucracies conclude that gender is embedded in power relations where specific types of gender configurations and struggles emerge in organisations. According to Duerst-Lahti and Kelly (1995) gender and power permeates all facets of human interaction and operates within society and institutions. Arguably, men have controlled social, political and economic institutions and have constructed these institutions to maintain power (ibid). Thus, men are generally advantaged in the institutions they have constructed (ibid). The reality for many women is that gender and power relations within organisations are patriarchal in nature (Duerst-Lahti \& Kelly, 1995; Nicolson, 1996; Mazur, 2002; Savage \& Witz, 1992; Stivers, 2002). Public and political life is the domain of men with women excluded or regarded as 'other' (Duerst-Lahti \& Kelly, 1995; Mazur \& Pollock, 2009). Bureaucracies are therefore gendered since the organisational dominance of men and control of power is to the disadvantage of women (Duerst-Lahti \& Kelly, 1995; Kelly \& Newman, 2001; Savage \& Witz, 1992). 
The organisational and bureaucratic configurations are such that, despite the introduction of gender equality legislation and policies in various countries, there is persistent gender inequality in public organisations. The increasing numbers of women entering the labour market and entering professional careers experience various forms of occupational gender segregation. In terms of vertical occupational segregation women still tend to be concentrated in lower ranks of the organisational hierarchy. In terms of horizontal occupational segregation, women tend to be concentrated in occupations associated with stereotypical feminine roles such as caring, empathy, etc. (Guy \& Newman, 2004). In public bureaucracies, it accounts for the higher level of female representation in health and education sectors such as nursing, teaching, and social caring jobs (ibid). There tends to be less representation of women in occupations and jobs associated with masculinity and traditionally associated with men (Duerst-Lahti \& Kelly, 1995; Guy \& Newman, 2004) such as the armed forces and law enforcement agencies. Occupational gender segregation has implications for public bureaucracy employees and recipients of public services. Scholars have documented the psychological, career, organisational, political and economic implications of occupational gender segregation and discrimination (see Duerst-Lahti \& Kelly, 1995; Mazur, 2002; McTavish \& Miller, 2006; Nicolson, 1996; Savage \& Witz, 1992; Stivers, 2002; Women \& Work Commission, 2006). Thus, bureaucracies are gendered in that the dominant norms and values are masculine (Duerst-Lahti \& Kelly, 1995). The gendered bureaucracies value masculine norms such as dominance, competitiveness, drive, assertiveness, rationality and dedication to the job which is inconsistent with stereotypical perceptions of feminine qualities (Stivers, 2002; Savage \& Witz, 1992; (Duerst-Lahti \& Kelly, 1995). It is what Kanter (1977) refers to as male homosociability where there is a 'bureaucratic kinship system' of men 'cloning' themselves in their own image, guarding access to power to those who fit their norms and thereby excluding feminine norms and women - maintaining patriarchal power.

Central to our argument is that it is the exact institutions - public bureaucracies - tasked with formulating and implementing gender equality policies which are gendered. For example, the European Commission (EC) has adopted gender mainstreaming as a policy, yet the EC itself is a gendered bureaucracy. The European Civil Service provides administrative, that is policy and legislative decision making support (the more prestigious service); and assistance, that is secretarial and clerical support to the European Commission, European Parliament, Council of the European Union, European Court of Justice and the European Court of Auditors. There is a high level of female employment in assistance compared to administrative services (EC 2010) - horizontal occupational gender segregation (Miller, 2012). Although, women account for the majority of those employed as assistants (65\%), there is a high proportion of men at senior levels of assistant services (EC, 2010; Miller 2012). Men dominate the most senior positions within the European Civil Service with representation at approximately $70 \%-$ vertical occupational gender segregation (ibid). Furthermore, male representation at senior levels within administrative services is $81 \%$ and in assistant services $76 \%$ (ibid). Feminist scholars would argue that the occupational gender segregation, with women in subservient and subordinate positions within the public bureaucracy hierarchy (vertical gender occupational segregation) and the division of labour (horizontal gender occupational segregation), is evidence of gender power relations (see Savage and Witz 1992) within EU institutions. The lack of passive representation has implications for the active representation of women in public policy. 


\section{Representative Bureaucracy Theory}

The theory of representative bureaucracy contends that there is a relationship between passive and active representation (see Brudney, Herbet \& Wright, 2000; Cayer \& Siegleman, 1980; Dolan, 2000; Dometrius, 1984; Hindera, 1993; Hindera \& Young, 1998; Keiser, Wilkins, Meier \& Holland, 2002; Meier, 1975; Meier \& Nicolson-Crotty, 2006; Mosher, 1982; Rehfuss, 1986; Riccucci, 1987; Riccucci \& Saidel, 1997; Saltzstein, 1983; 1986; Selden, Brudney \& Kellough, 1998; Weldon, 2002; Wilkins, 2006; Wilkins \& Keiser, 2004; Wise, 2003). According to Mosher (1982) passive representation is concerned with representatives, as proportion of the population, having the same demographic origins (gender, race, income, class, religion, etc.) as the population it serves. Similarly, Lovenduski (2005) states that descriptive representation is the notion that a proportion of the population is being represented within an organization. Thus, passive or descriptive representation involves a section of a population with the same demographic origins included in an organisation. In terms of active representation, representatives actively advance the interests of a group (Mosher, 1982). Mansbridge (1999) argues that descriptive characteristics act as a proxy for identifying shared experiences which results in active representation when a person is most similar to a group and acts in their interests. Thus, when representatives with similar descriptive characteristics act for those they represent, they are substantively representing the interests of their demographic group (Pitkin, 1967). Some scholars (see Kelly \& Newman, 2001; Weldon, 2002) refer to active representation as the substantive representation of group interests. Representative bureaucracy theory therefore 'assumes that shared experiences and values, which may not be shared across gender or race divisions, fundamentally affect the decisions made by and the actions taken by bureaucrats' (Meier \& Nicolson-Crotty, 2006). Thus, the theory of representative bureaucracy holds that the gender and/or race of the bureaucrat affects the relationship that the bureaucrat has with a citizen or recipient of a public agency's service (Keiser et al, 2002; Meier \& Nicolson-Crotty, 2006; Riccucci \& Saidel, 1997; Thielemann \& Stewart, 1996; Weldon, 2002; Wilkins \& Keiser, 2004).

Representative bureaucracy scholars have probed whether passive representation of females within public bureaucracies leads to policy outcomes that benefit women as a group (Dolan 2001). There are a range of studies which provide evidence of active representation in terms of favourable policy outcomes for particular groups (see Keiser et al, 2002; Meier, 1993; Meier \& Nicolson-Crotty, 2006; Meier \& O'Toole, 2006; Meier \& Stewart, 2002; Wilkins, 2006; Wilkins \& Keiser, 2006). For example, Meier and Nicholson-Crotty's (2006) study of the police found that where there were higher levels of female police officers, there were higher rates of arrest related to sexual violence such as rape with the converse also holding true in their study. The result of higher arrest rates for gender based violence had positive outcomes for women (ibid). Research also shows a range of bureaucratic and organisational intervening factors: individual bureaucratic discretion can lead to higher active representation (e.g. Dolan \& Rosenbloom, 2002; Meier \& Bohte, 2001); salience both in terms of individual bureaucrat demographic identity (e.g. Keiser et al, 2002) and symmetry between bureau organisational goals and specific policy arenas (Kelly and Newman, 2001; Lovenduski et al, 2005); inter-sectionality of several identities and characteristics (e.g. Meier, Pennington \& Elder, 2005 research of the US Equal Employment Opportunity Commission); and position in organisation hierarchy with some research showing greater dynamic for active representation at higher levels (e.g. Pitts, 2005), some showing more effects at lower levels (e.g. Meier, 1993) and some showing effects only at the highest levels (e.g. Dolan, 2001). 
The review of representative bureaucracy research shows that the translation of passive to active representation occurs under certain conditions. Firstly, the policy area is one where bureaucrats have discretion in order to exercise active representation (Keiser et al, 2002; Mosher, 1982; Sowa \& Selden, 2003; Wilkins \& Keiser, 2004). Discretion is a necessary condition because it provides bureaucrats with the opportunity to shape outputs and rewards for a particular group (Mosher, 1993; Sowa \& Selden, 2003; Wilkins \& Keiser, 2004). Second, the policy area should be salient for the demographic characteristics in question - the implementation of the policy must benefit a group (Keiser et al, 2002; Mosher, 1982; Wilkins \& Keiser, 2004; Wise, 2003). Sowa and Selden (2003) and Keiser et al (2002) argue that if an organisation's goals are inconsistent with acting on behalf of clients, it is less likely that representative bureaucracy will occur. Third, when women are represented at senior echelons of bureaucracies they should have the authority to represent women actively (Dolan, 2000; 2001). Moreover, much of the research empirically demonstrates that the passive representation of women, under the aforementioned conditions, can lead to the active representation of women with positive policy outcomes.

\section{Strategies and Representative Bureaucracy}

There have been various strategies over the decades to improve the representation of minorities and women in public bureaucracies. However, as scholars and the data of various governments (within the EU and in the US) show there has been very slow 'progress' towards addressing gender inequality in public bureaucracies. These various strategies could be classified into 'soft' strategies such as diversity training, monitoring and awareness to 'hard' strategies such as positive action, affirmative action and quotas. It is beyond the scope of this paper to comprehensively explore every strategy to improve representation in bureaucracies (for a good review we suggest Riccucci, 2002). Nonetheless, we argue that the weakness of many of the strategies is that it does not fundamentally challenge the masculinity of public bureaucracies. A case in point is gender mainstreaming, the preferred strategy adopted by the EU.

Gender mainstreaming has gained policy impetus at international (e.g. EU and UN) levels. It is a process assessing the implications for men and women of any organisational action in all areas and at all levels (Rai, 2003; Rees, 1998). It requires the identification of gender issues in the design, implementation and evaluation of the full range of organisational practices and procedures (see Rubery, 2002). The idea and conceptualization of gender mainstreaming gained prominence at the United Nations Beijing Conference on Women (1995) where governments committed themselves to mainstream gender equality throughout policy processes (Woodward, 2003). Gender mainstreaming was adopted by the Council of Europe as the '...(re)organisation, improvement, development and evaluation of policy processes, so that a gender equality perspective is incorporated in all policies at all levels and at all stages, by actors normally involved in policy-making' (Council of Europe, 1998:15).

However there are significant aspects of mainstreaming which may qualify or indeed question its adoption as a strategic action to address shortcomings in bureaucratic representation. There are two sets of questions: first about the implementation of mainstreaming; and second more fundamentally about the broader public policy frame within which mainstreaming occurs in public sector organisations. Research shows that many supranational institutions and their bureaucratic structures have a preference for soft measures believing that in the long term these are more likely to gain compliance, with harder 
measures likely to lead to superficial compliance (Hafner-Burton \& Pollack, 2009; Weaver, 2008). The EU, with various road maps, has shown a preference for a soft approach in the implementation of gender mainstreaming (Hafner-Burton \& Pollack, 2009). An adverse impact of soft compliance is that mainstreaming initiatives and practices can disappear from policy and organisational agendas (Woodward, 2003; Miller, 2009). Additionally, there may be downgrading of the support infrastructure required for mainstreaming, for example budget squeezing, reductions in training and development provision - and indeed there is some evidence for this at EU level (see European Women's Lobby, 2007; Hafner-Burton \& Pollack, 2009).

Second, the public policy frame within which mainstreaming is introduced may not be particularly well suited to increasing representation in the bureaucracy. It is argued within the EU mainstreaming has been co-opted to service the dominant economic policy frame (some have gone so far as to say that mainstreaming is 'rhetoric without substance' - see Stratigaki, 2005: 180). Gender mainstreaming has become pre-occupied with an unequivocal instrumental link to employment policies and is defined largely in terms of increased labour market participation by women allied to flexibility (see Shaw, 2002). Such a perspective will not necessarily see mainstreaming as helpful in increasing representation (certainly not active representation) in public bureaucracies. The increased labour market participation of women and equal opportunities discourses has seen an intensification of the diversity of working hours with the relative disadvantage for women (Rubery, 2001). Thus, gender mainstreaming in policy has in fact extended a capitalist and neo-liberal agenda of increasing the labour productivity of women rather than achieving the objective of equality per se. For example, Stratigaki (2004) argues that gender mainstreaming has become co-opted through a growing dominance of economic priorities such as the reconciliation of work-life policies. Stratigaki (2004:50) argues that 'The process of cooption of the gender equality concept...exemplifies how the outcome of conflicting policy frames in the EU is shaped, as well as how policy opportunities and barriers are evolving throughout the project of European integration...the policy goal of involving flexibility of the labour market eventually prevailed over gender equality objectives for framing reconciliation, resulting in the cooption of the concept. This cooption transformed and corrupted its meaning.'

The implementation of gender mainstreaming across European national administration has to a large extent been limited (see Hafner-Burton \& Pollack, 2009; Stratgaki, 2004; 2005; Verloo, 2001). It is difficult to implement gender mainstreaming effectively when there are embedded masculine values (Stratgaki, 2005). Even the EC has acknowledged that the mainstreaming of gender equality in policy and public service practices has not been achieved - hence the latest road map for gender equality (see http://europa.eu/legislation_summaries/employment_and_social_policy/equality_between_m en_and_women/c10404_en.htm). The EC has nonetheless persevered with the gender mainstreaming strategy. As discussed above the strategy largely involves a soft option and voluntary compliance. Arguably, the soft option is a reaction to the Kalanke Judgment ${ }^{\mathrm{i}}$ (European Court of Justice Case C-450/93) and compliance with a founding directive - equal treatment in employment (Council Directive 76/207/EEC). The ruling effectively prohibited positive action in the EU (see Hodges-Aeberhard, 1999).

Given the limited effectiveness of 'soft' strategies and the paucity of women in public bureaucracies, there is a prima facie case for quotas, affirmative or positive action. Some critics believe that quotas can lead to tokenism and therefore rather than advancing women's 
representation may become an instrument of gender patronage (see Dahlerup \& Friedenvall, 2010). An important aspect of quotas, targets and related actions is the notion of soft and hard measures used to reach the representation required. A range of soft but consistently applied measures has been shown to achieve success. For example in New Zealand the activities of bodies such as the Ministry of Women's Affairs Nominations Service which provides a database of suitably qualified women, the Crown Companies Monitoring Advisory Unit and an Equal opportunities Employment Trust support: organisation of education and training seminars; awareness raising occasions; encouragement of the use of the Nominations Service database (Casey at al 2010). Other countries (e.g. Norway) have adopted a non voluntaristic approach and have legislated quotas (ibid). There are however a range of unintended consequences. In bureaucratic environments where there may be limited numbers of women qualified in the short term for some of the most senior positions, there can be 'over stretch' and a feeling of obligation to assume 'quota responsibilities' irrespective of whether the individual feels personally ready (ibid). That said though, on the balance of argument the hard versus soft favours the former. Research on a range of organisations carried out in the USA (using Federal data 1971-2002) indicated that of the variety of practices used to advance the representation of specific groups (women and minority employees), the softer approaches of training, mentoring and networking were modest in success compared to the harder approach of establishing a responsibility structure and making individuals in this structure accountable for actions (Kalev et al, 2006). There are also the consequences of such actions which may require addressing. In Schofield and Goodwin's regime of 'feminist presence and masculinist backlash' one scenario is that gender specific actions which are feminist in intent will face barriers when confronted with masculinized power, barriers which will be at best indifferent, at worst hostile, to women's interests (Schofield \& Goodwin, 2005).

Linked conceptually to increasing representation through targets, quotas, hard and soft measures are the notion of critical mass (Kanter, 1977). Critical mass concerns the relationship between passive and active representation and is sometimes depicted as a specific point when a certain proportion is reached. Although some scholars, when studying the impact of elected representatives on policy outcomes do suggest a critical representation threshold (for a good account see Beckwith, 2007) the concept is under theorized (ibid). Kanter's approach in fact is based on proportionality in terms of passive representation. She categorized uniform groups, skewed groups (large preponderance of one type over another), tilted groups (where ratio of majority to minority is closer) and balanced (Kanter, 1977) with the assumption that passive would lead to active representation of women.

Gender mainstreaming and positive action, whether 'soft' or 'hard' strategies, to improve representation in public bureaucracies, are not without implementation problems with various unintended outcomes. Why is this? We argue that whatever strategy is adopted to improve representative bureaucracy has to take into consideration the organisational context (see Brudney, Herbet \& Wright, 2000; Keiser et al, 2002; Meier \& Nigro, 1976; Rehfuss, 1986; Riccucci, 1995; Rosenbloom \& Kinnard, 1977; Saidel \& Loscocco, 2005; Saltzstein, 1979; Selden et al, 1998). In particular, to address persistent gender inequality, the masculine context and values of organisations have to be taken into consideration. As discussed above public bureaucracies are not gender neutral but rather the domain of masculinity. Furthermore, a 'one size fits all' strategy to improve representation without taking into consideration the organisational context and indeed the extant level of representation in a public bureaucracy is bound to experience limits in implementation. Thus we argue that to effectively implement a strategy to improve representation of a public bureaucracy one first 
needs to understand the organisation in terms of its context, function, representation and values (Saidel \& Loscocco, 2005). We draw upon extant research in this area, in particular Kelly and Newman (2001) study, to develop a typology of representative bureaucracy.

\section{Representative Bureaucracies: A Typology}

We argue that representative bureaucracy is complex with interactions between organisational context, function, values and the representation of women within a public bureaucracy. We attempt to illustrate the complexity of these interactions with a typology as illustrated in Figure 1.

\section{[Insert Figure 1 here]}

Quadrant 1 (Q1) represents public bureaucracies where there is a high level of women represented in the organisation. Together with the high level of passive representation there are also high levels of active representation with policy benefits for women. We would classify public bureaucracies concerned with equal employment opportunities within Q1. Thus, the public agencies' mission, values function and representation within the organisation are congruent with policy outcomes. Hindera and Young (1998) in their research of the Equal Employment Opportunities Commission (EEOC) found that when there is a critical mass of passive representation, active representation transpires. They found that '...plurality and majoritarian models strongly suggest that bureaucracies can be staffed in such a way as to produce hyper-responsiveness toward specific clientele' (Hindera \& Young, 1998:668). Thus, public bureaucracies with a critical mass together with hyper-responsiveness to clients and a value of equality will most likely achieve higher levels of active representation.

Quadrant $2(\mathrm{Q} 2)$ is represented as public bureaucracies where there are low levels passive representation, yet there are relatively high levels of active representation. In other words, despite the relatively low rate of female representation there are beneficial policy outcomes for women. However, this only occurs when: (1) there are femocrats active within the public bureaucracy (see Chappell, 2002); and/or (2) there is an alignment of organisational policy goals where the public agency derives some benefit from the active representation of women (Newman, 1995). Femocrats are bureaucrats who champion or advocate for the active representation of women in public policy (Chappell, 2002), have a level of technical expertise to advance women's rights (Curtin, 2008; Miller, 2009; 2012) and tend have seniority with commensurate authority (see Dolan, 2000). Dolan (2000:525) for example found that women in the senior executive service '...have already reached the pinnacle of their career service, attitudes or efforts geared towards improving women's status in the workplace may simply be less risky for them.' There is value congruence between femocrats and women within and outside the organisation (see Sowa \& Selden, 2003) and they may for example draw upon policy networks to advance the interest of women (see Mazur, 2002). While it is true femocrats could exist within any public bureaucracy, femocrats we argue play a significant role in advocating active representation of women in a predominately masculine bureaucracy.

Why would a Q2 type organisation, a predominately masculine public bureaucracy, entertain the active representation of women? A further explanation is that the public agency and those employed within the agency derive a benefit. In others words despite low levels of female passive representation, there is active representation because it benefits the agency. Public choice theory would in part explain the behaviour. An example of this would be public 
agencies involved in distributive social security benefits such as child benefits (see Wilkins, 2006). As in most countries, in Europe it is women and their children, relative to men, who live in poverty and are often recipients of welfare and/or child benefits (see EC, 2008). It would be of interest to the public agencies to provide benefits to women to increase resourcing to the agency. Although many of the women employed in these agencies are frontline workers engaged in clerical administration (see Guy \& Newman, 2004; Riccucci \& Meyers, 2003; Wilkins, 2006) and there tends to be vertical gender occupational segregation with most men occupying supervisory or managerial positions within these agencies.

Quadrant 3 (Q3) involves the high passive representation yet low active representation of women. This is counter-intuitive to proponents of critical mass theory and indeed those who argue that passive representation is necessary for active outcomes. Yet there are public agencies with high passive but low active representation of women. This phenomenon occurs when organisational practices and incentives encourage the assimilation of women into a predominantly masculine organisational culture. As Kanter (1977) suggests the women in a predominantly masculine organisation are subject to 'loyalty tests'. In other words, female bureaucrats adopt masculinist norms and are less sympathetic to other women in the organisation (see Gini, 2001). In academic literature these women are referred to as 'queen bees' - successful women unwilling to accept that other women are capable of organisational advancement without favour (Abramson, 1975; Mavin, 2008). These senior female personnel behave in a misogynistic manner towards both men and women (Wacjman, 1998). Research has shown these barriers prevalent in parts of major public bureaucracies, for example in higher education (Mavin et al, 2006), local authorities and third sectors (Gini, 2001). Stivers (2002) for example argues that the assimilation of women in public bureaucracies is in part explained by new public management performance regimes. A further explanation for high passive representation yet low active representation is that organisational constraints prevent the exercise of discretion to represent women actively (see Scott, 1997). Meier and Bohte (2001) in their research of schools in the US found that the performance of minority students only improved when the organisational structures promoted rather than limited minority teacher discretion to assist their minority students. Other research found that, although the majority of the public education sector employees are women, they actively represent women when the organisational structures and practices enable the behaviour (McTavish \& Miller, 2006; Whitehead \& Moodley, 1999). Discretion is an important variable in the translation of passive to active representation (Meier, 1993; Meier \& Bohte, 2001; Meier \& Stewart, 1992; Riccucci \& Meyers, 2003; Scott, 1997; Sowa \& Selden, 2003; Thielemann \& Stewart, 1996; Wilkins \& Keiser, 2004). As Sowa and Selden (2003:706) argues, '...when administrators perceive themselves as having little discretion, they will not take risks and make decisions that reflect their personal values and beliefs; they will not become active representatives of minority interest.'

Although Q1 to Q3 illustrates the nuances of representative bureaucracies which may exist, Quadrant $4(\mathrm{Q} 4)$ is perhaps the hegemonic view of low passive and active representation of women in public bureaucracies. Q4 therefore typifies a masculine public agency of low passive and active representation of women. Women in these organisations as employees or those who engage with these agencies as clients are often marginalized and discriminated against. They face numerous organisational barriers and practices which inhibit representative bureaucracy. An example of a Q4 public agency would be law enforcement where there are persistently low levels of female passive representation and poor active representation for women. There have been various studies over the years which have 
illustrated the poor outcomes for women in Q4 type organisations (see Cayer \& Sigelman, 1980; Dolan, 2000; 2001; 2004; Dometrius, 1984; Duerst-Lahti \& Kelly, 1995; Guy, 1993; Guy \& Newman, 2004; Keiser et al., 2002; Kelly \& Newman, 2001; Mansbridge, 1999; Mazur, 2002; McBride \& Mazur, 2010; McTavish \& Miller, 2006; Nicolson, 1996; Rehfuss, 1986; Saltzstein, 1983; 1986; Savage \& Witz, 1992; Stivers, 2002; Sigelman, 1976; Weldon 2002).

We share the view with feminist scholars that the state and its public agencies are predominantly masculine. We adopt a normative approach that low representation of women (passive and active representation) ought to be addressed to advance the human, socioeconomic and political rights of women. We therefore in the following section discuss potential strategies for public organisations to achieve representative bureaucracy vis-à-vis the typology.

\section{Towards Institutional Strategies for Representative Bureaucracy}

The complexity of public bureaucracies in terms of organisational context, structure, values, functions, etc. and extant representation requires strategies which are not generic. We argue that, given the organisational complexities, it would not be appropriate to adopt a 'one size fits all' approach. For example, it would not be appropriate to employ gender mainstreaming or positive action for Q1 type agencies. We argue that to improve the representation of women there needs to be a multifaceted approach which challenges the masculinity of organisations. A starting point would be positive action to increase the critical mass and passive representation of women in public bureaucracies. This would require a rethink and revisions of current EU directives and strategies. Indeed, how can the directive of equal treatment in employment be upheld (European Court of Justice Case C-450/93) when equality does not exist?

We agree with the arguments of Hodges-Aeberhard (1999) in her global, comparative review and analysis of positive and affirmative action that: (1) the concept of positive action has to be defined (in part to avoid co-option of the equality agenda as discussed by Stratigaki (2005), and to provide strategic direction); (2) positive action does not constitute 'reverse' discrimination; (3) there are potential limits; (4) exemplars (e.g. Q1) and the successes should be disseminated when aims are achieved; (5) guidance should be given on the relative claims of individual and group damage; (6) there should be clarification on the balance to be reached in respecting/diminishing other groups' rights; and (7) a stand be taken on the egregious nature of the discrimination to be overcome. We also argue that in addition to these actions appropriate strategies need to be developed to increase the active representation of women.

Thus, for Q4 type agencies it would be appropriate to introduce 'hard' strategies, i.e. positive action in conjunction with targets, monitoring of compliance, sanctions for non-compliance and introduce 'soft' strategies such as training. Q1 type agencies could be used as exemplars to provide an evidence base for the benefits of representative bureaucracy and champion strategies to improve equality. In the case of public agencies in Q2 and Q3 the masculine organisational context needs to be challenged as well. This would involve strategies to change the organisational practices and incentives. Thus for Q2 type agencies positive action to increase a critical mass and improve the passive representation of women would be necessary. In addition Q2 type agencies could build upon existing good practice of active representation through gender mainstreaming throughout the organisation, involving women 
policy networks to build upon initial gains. Q3 type agencies also require a strategy challenging the existing masculine organisational practices and changing incentives. Thus practices which enable discretion and/or incentives (e.g. performance regimes) which value active representation should be promoted and advanced in the organisation. Therefore, dependent on the level of passive and active representation of a public agency a multifaceted strategy, drawing upon good practices and lessons, could be employed to improve the representation of public bureaucracies. Moreover, strategies which challenge the masculine hegemony of the state and public agencies should be the underlying outcome of any strategy to truly achieve representation with positive outcomes for women and indeed equality in public sector employment. Adopting merely one strategy to be implemented throughout all organisational types (e.g. gender mainstreaming) may not effectively achieve representative bureaucracies, rather it may result in unintended outcomes such as masculine backlash or assimilation of women.

\section{Conclusion}

This paper reviewed extant research on the gendered nature of public bureaucracies as domains of masculinity and the theoretical perspectives of representative bureaucracy. We have argued that existing strategies to improve the representation of women in European public administrations (e.g. gender mainstreaming) have largely been ineffective. We have therefore suggested a normative typology of institutional strategies - depending on levels of representation, values, context and function of the bureaucracy - to be implemented in order to improve the levels of passive and active representation of women. We suggest that there needs to be a critical examination of strategies for representative bureaucracy comparatively and within various organisational contexts. We observe, as have others, that representative bureaucracy is an under-researched area and yet is fundamental to good governance - the lack of representation in bureaucracies arguably represents a democratic deficit and moreover results in poor policy outcomes for women. There are few scholars (mostly cited within this paper) who investigate gender and representative bureaucracy and we encourage scholars to engage in this important research area by, for example, testing the validity of the typology. As Wilkins (2006:79) argues, 'unlike research on race and ethnicity, the research examining active representation and the sex of bureaucrats is sparse...' Thus, we encourage scholars, particularly in Europe, since much of the research in this area emanates from the US, to investigate gender and representative bureaucracy with a view to critically examining strategies to achieve a representative bureaucracy.

\section{References}

Abramson, J. (1975) The Invisible Woman: Discrimination in the Academic Profession, London: Josey Bass

Beckwith, K. (2007) 'Numbers and Newness: The Descriptive and Substantive Representation of Women', Canadian Journal of Political Science, 40(1): 27-49.

Brudney, J.J, Herbert, F.T and Wright, D.S. (2000) 'From Organisational Values to Organisational Roles: Examining Representative Bureaucracy in State Administration', Journal of Public Administration Research and Theory, 10 (3): 491-521.

Casey, C., Skibnes, R. and Pringle, J.K. (2010) 'Gender Equality and Corporate Governance: Policy Strategies in Norway and New Zealand', Gender Work and Organisation DOI: 10:1111/j.1468-0432.2010.00514x 
Cayer, N.J. and Sigelman (1980) 'Minorities and Women in State and Local Government: 1973-1975', Public Administration Review, 40 (5): 443-450.

Chappell, L. (2002a) "The "Femocrat" Strategy: Expanding the Repertoire of Feminist Activities', Parliamentary Affairs, 55: 85-98.

Council of Europe (1998) Gender Mainstreaming: Conceptual Framework, Methodology and Presentation of Good Practices. Strasbourg: Council of Europe, EG-S-MS (98) 2.

Curtin, J. (2008) 'Women, Political Leadership and Substantive Representation: The Case of New Zealand', Parliamentary Affairs, 61(3):490-504. .

Dahlerup, D. and Friendenvall, L. (2010) 'Judging Gender Quotas: Predictors and Results', Policy and Politics, 38(3):407-425.

Dolan, J. (2000) 'The Senior Executive Service: Gender, Attitudes, and Representative Bureaucracy', Journal of Public Administration Research and Theory, 10 (3): 513-529.

Dolan, J. (2001) 'Women in the Executive Branch: A Review Essay of Their Political Impact and Career Opportunities', Women \& Politics, 22 (4): 89-104.

Dolan, J. (2004) 'Gender Equity: Illusion or Reality for Women in the Federal Executive Service', Public Administration Review, 64 (3): 299-308.

Dolan, J. and Rosenbloom, D.H. (eds.) (2003) Representative Bureaucracy: Classic Readings and Continuing Controversies. Armonk, N.Y.: M.E. Sharpe.

Dometrius, N.C. (1984) 'Minorities and Women Among State Agency Leaders', Social Science Quarterly, 65 (1): 127-137.

Duest-Lahti, G. and Kelly, R.M. (ed.) (1995) Gender, Power, Leadership and Governance, Ann Arbor: The University of Michigan Press.

European Commission (2008) The Life of women and Men in Europe: a statistical portrait, Luxembourg: EUROSTAT.

European Commission (2010) More women in senior positions: key to economic stability and growth, Brussels: European Commission, Directorate-General for Employment, Social Affairs and Equal Opportunities.

European Women's Lobby. (2007) Evaluation of the Implementation of the European Commission's Roadmap for Equality Between Women and Men 2006-2010 - Year One. http:// www.womenlobby.org/site/abstract/asp? Doc ID=2040\&V.11D (accessed December 2010)

Gini, A. (2001) My Job My Self: Work and the Creation of the Modern Individual, London: Routledge.

Gierycz, D. (1999) 'Women in Decision Making: Can We Change the Status Quo?' in Breines, I., Giervcz, D. and Reardon, B.A. (eds) Towards a Women's Agenda for a Culture of Peace 19-30, Paris:UNESCO.

Guy, M.E. (1993) 'Three Steps Forward, Two Steps Backward: The Status of Women's Integration into Public Management', Public Administration Review, 53 (4):285-292.

Guy, M.E. and Newman, M.A. (2004) 'Women's Jobs, Men's Jobs: Sex Segregation and Emotional Labour', Public Administration Review, 64 (3): 289-298.

Hafner-Burton, E.M. and Pollack, M.A. (2009) 'Mainstreaming gender in the European Union: Getting the incentives right', Comparative European Politics, 7 (1): 114-138/

Hale, M.M. (1996) 'Gender Equality in Organisations: Resolving the Dilemnas, Review of Public Administration, 16(1): 7-18.

Hindera, J. J. (1993) 'Representative bureaucracy: Further evidence of active representation in the EEOC district offices', Journal of Public Administration Research and Theory, 3 (October): 415-430.

Hindera, J.J. and Young, C.D. (1998) 'Representative Bureaucracy: The Theoretical Implications of Statistical Interaction', Political Research Quarterly, 51 (3): 655-671. 
Hodges-Aeberhard, J. (1999) 'Affirmative action in employment: Recent court approaches to a difficult concept', International Labour Review, 138 (3): 247-272.

Kalev, A., Dobbin, F. and Kelly, E. (2006) 'Best Practice or Best Guesses? Assessing the Efficacy of Corporate Affirmative Action and Diversity Policies', American Sociological Review, 71: 589-617.

Kanter, R.M. (1977) Men and Women of the Corporation, New York: Basic Books.

Keiser, L.R., Wilkins, V.M., Meier, K.J. and Holland, C. (2002) 'Lipstick and Logarithms: Gender, Institutional Context, and Representative Bureaucracy', American Political Science Review, 96 (3): 553-564.

Kelly, R.M. and Newman, M. (2001) 'The Gendered Bureaucracy: Agency Mission, Equality of Opportunity, and Representative Bureaucracies', Women \& Politics, 22 (3): 1-33.

Kerr, B., Miller,W. and Reid, M. (2002) 'Sex Based Occupational Segregation in the US State Bureaucracies 1987-97', Public Administration Review, 62(4): 412-423

Lovenduski, J. (2005) Feminizing Politics, Cambridge: Polity Press.

Lovenduski, J. (ed. with Baudino, C., Guadagnini, M., Meier, P. and Sainsburg, D.) (2005) State Feminism and Political Representation, Cambridge: Cambridge University Press.

Mansbridge, J. (1999) 'Should Blacks Represent Blacks and Women Represent Women? A Contingent "Yes", Journal of Politics, 61 (3): 628-657.

Mavin, S., Bryans, P. and Waring, T. (2006) 'Challenging gendered leadership and management education' in D. McTavish and K. Miller (eds.) Women in Leadership and Management, Cheltenham: Edward Elgar.

Mavin, S. (2008) 'Queen Bees, Wannabees and Afraid to Bees: No More 'Best Enemies' for Women in Management?', British Journal of Management, 19: 75-84.

Mazur, A. G. and Pollock (ed.) (2009) 'Gender and Public Policy in Europe', Special Issue of Comparative European Politics, 9 (1).

Mazur, A.G. (2002) Theorizing Feminist Policy, Oxford: Oxford University Press.

McBride, D. and Mazur, A.G. (2010) The Politics of State Feminism, Philadelphia: Temple University Press.

McTavish, D. and Miller, K. (eds.) (2006) Women in Leadership and Management, New Horizons in Management Series Editor: Cary L. Cooper, Cheltenham: Edward Elgar.

Meier, K.J. (1975) 'Representative Bureaucracy: An Empirical Analysis', The American Political Science Review, 69 (2): 526-542.

Meier, K.J. (1993) 'Latinos and Representative Bureaucracy: Testing the Thompson and Henderson Hypotheses', Journal of Public Administration Research and Theory, 3 (4) 393-414.

Meier, K.J. and Bohte, J. (2001) 'Structure and Discretion: Missing Links in Representative Bureaucracy', Journal of Public Administration Research and Theory, 11 (4): 455-470.

Meier, K.J. and O’Toole, L.J. Jnr. (2006) Bureaucracy in a Democratic State, Baltimore MD: John Hopkins University Press.

Meier, K.J., Pennington, M.S.and Elder, W.S. (2005) 'Race Sex and Clarence Thomas: Representation Change in the EEOC', Public Administration Review, 65(2): 171-179.

Meier, K.J. and Nicholson-Crotty, J. (2006) 'Gender, Representative Bureaucracy, and Law Enforcement: The Case of Sexual Assault', Public Administration Review, November/December: 850-860.

Meier, K.J. and Nigro, L. G. (1976) 'Representative Bureaucracy and Policy Preferences: A Study in Attitudes of Federal Executives', Public Administration Review 36 (4):458-69.

Meier, K.J. and Stewart, J, Jr. (1992) 'The Impact of Representative Bureaucracies: Educational Systems and Public Policies', American Review of Public Administration 22 (3): $157-71$. 
Meier, K.J and Wilkins, V.M. (2002) 'Gender Differences in Agency Head Salaries', Public Administration Review 62: 397-403

Miller, K. J. (2009) 'Public Policy Dilemma - Gender Equality Mainstreaming in UK Policy Formulation', Public Money and Management, 29 (1): 43-50.

Miller, K.J (2012) 'Representative Bureaucracy and Multilevel Governance in the EU', Geopolitics, History and International Relations, 4 (1): 50-75.

Mosher, F. (1982 $2^{\text {nd }}$ edition) Democracy and the public service, New York: Oxford University Press.

Newmand, M. A. (1995) 'The Gendered Nature of Lowi's Typology; or, Who Would Guess You Could Find Gender Here?' in G. Duerst-Lahti and R.M. Kelly (eds.) Gender Power, Leadership, and Governance, Ann Arbor: University of Michigan Press, 141-164.

Nicolson, P. (1996) Gender, Power and Organisation, London: Routledge.

Pitkin, H.F. (1967) The Concept of Representation, Berkeley: University of California Press.

Pitts, D.W. (2005) 'Diversity Representation and Performance: Evidence About Race and Ethnicity in Public Organisations', Journal of Public Administration Research and Theory, 15(4): 615-631.

Rai, S. (2003) Mainstreaming Gender, Democratising the State?, Manchester: Manchester University Press.

Rehfuss, J.A. (1986) 'A Representative Bureaucracy? Women and Minority Executives in California Career Service', Public Administration Review, 46 (5): 454-460.

Rees, T. (1998) Mainstreaming Equality in the European Union: Education, Training and Labour Market Policies, London: Routledge.

Riccucci, N.M. (1987) 'Black Employment in Municipal Workforces', Public Administration Quarterly, 11(1): 76-89.

Riccucci, N.M. (1995) Unsung heroes: federal executives making a difference. Washington, DC: Georgetown University Press.

Riccucci, N.M. (2002) Managing Diversity in Public Sector Workforces, Boulder, CO.: Westview Press.

Riccucci, N.M. and Meyers, M.K. (2003) 'Linking Passive and Active Representation: The Case of Front-Line Workers in Welfare Agencies', prepared for the $7^{\text {th }}$ Public Management Research Conference, Georgetown University, Washington, D.C., October 9 $-11,2003$.

Riccucci, N.M. and Saidel, J.R. (1997) 'The Representativeness of State-Level Bureaucratic Leaders: A Missing Piece of the Representative Bureaucracy Puzzle', Public Administration Review, 57 (5): 423-430.

Rosenbloom, D.H. and Kinnard, D. (1977) 'Bureaucratic Representation and Bureaucrats' Behaviour: An Exploratory Analysis', The American Review of Public Administration, 11 (1): 35-60.

Rubery, J. (2001) 'Equal Opportunities and Employment Policy', in Auer, P. (ed) Changing Labour Markets in Europe, ILO Books.

Rubery (2002) 'Gender Mainstreaming and Gender Equality in the EU Employment Strategy', Industrial Relations Journal, 33(5): 30-56.

Saidel, J.R. and Loscocco, K. (2005) 'Agency Leaders, Gendered Institutions, and Representative Bureaucracy'. Public Administration Review 65 (2): 158-70.

Saltzstein, G.H. (1979) 'Representative Bureaucracy and Bureaucratic Responsibility: Problems and Prospects', Administration and Society, 10 (4): 464-75.

Saltzstein, G.H. (1983) 'Personnel Directors and Female Employment Representation: A New Addition to Models of Equal Opportunity Policy?', Social Science Quarterly, 64(4): 734-746. 
Saltzstein, G.H. (1986) 'Female Mayors and Women in Municipal Jobs', American journal of Political Science, 30(1): 140-164.

Savage, M. and Witz, A. (eds.) (1992) Gender and Bureaucracy, Oxford: Blackwell Publishers.

Schofield, T. and Goodwin, S. (2005) 'Gender Politics and Public Policy Making: Prospects for Advancing Gender Equality', Policy and Society, 24(4): 1-20.

Scott, P.G. (1997) 'Assessing Determinants of Bureaucratic Discretion: An Experience in Street-Level Decision Making', Journal of Public Administration Research and Theory, 7 (1): 35-57.

Selden, S.C., Brudney, J.L. and Kellough, J.E. (1998) 'Bureaucracy as a Representative Institution: Toward a Reconciliation of Bureaucratic Government and Democratic Theory', American Journal of Political Science, 42 (3): 717-744.

Shaw, J (2002) 'The European Union and Gender Mainstreaming: Constitutionally Embedded or Comprehensively Marginalised?', Feminist Legal Studies, 10(3): 213-226.

Sowa, J.E. and Selden, S.C. (2003) 'Administrative Discretion and Active Representation: An Expansion of the Theory of Representative Bureaucracy', Public Administration Review, 63 (6): 700-710.

Stetson, D.M and Mazur, A. (eds.) (1995) Comparative State Feminism, Thousand Oaks: Sage

Stivers, C. (2002) Gender Images in Public Administration: Legitimacy and the Administrative State, Thousand Oaks, California: Sage Publications.

Stratigaki, M. (2004) 'The Cooptation of Gender Concepts in EU Policies: The Case of "Reconciliation of Work and Family", Social Politics, 11 (1): 30-56.

Stratigaki, M. (2005) 'Gender Mainstreaming vs. Positive Action: An Ongoing Conflict in EU Equality Policy’, European Journal of Women's Studies, 12 (2): 165-186.

Thielemann, G.S. and Stewart, J. (1996) 'A Demand-Side Perspective on the Importance of Representative Bureaucracy: AIDS, Ethnicity, Gender, and Sexual Orientation', Public Administration Review, 56 (2): 168-173.

Verloo, M. (2001) Another Velvet Revolution? Gender Mainstreaming and the Politics of Implementation, IWM Working Paper, No. 5/2001 (IWM Publications, Vienna).

Wacjman, J. (1998) Managing Like a Man: Women and Men in Corporate Management, Cambridge: Cambridge University Press.

Weaver, C. (2008) The Strategic Construction of the World Bank's Gender and Development Agenda, paper presented at the International Studies Association Annual Meeting 25 ${ }^{\text {th }}$ March, San Francisco, CA. Cited in Hafner-Burton and Pollack (2009).

Weldon, S.L. (2002) 'Beyond Bodies: Institutional Sources of Representation for Women in Democratic Policymaking', The Journal of Politics, 64 (4), pp. 1153-1174.

Whitehead, S. and Moodley, R. (eds.) (1999) Transforming Managers: Gendering Change in the Public Sector, London: UCL Press.

Wilkins, V. M. (2006) 'Exploring the Causal Story: Gender, Active Representation, and Bureaucratic Priorities', Journal of Public Administration Research and Theory, 17 (January): 77-94.

Wilkins, V.M. and Keiser, L.R. (2004) 'Linking Passive and Active Representation by Gender: The Case of Child Support Agencies', Journal of Public Administration Research and Theory, 16: 87-102.

Wise, L.R. (2003) 'Representative Bureaucracy', in B.G. Peters and J. Pierre (2003) Handbook of Public Administration, Thousand Oaks, California: Sage.

Women and Work Commission (2006) Women and Work Commission Report: Shaping a Fairer Future, Women and Work Commission: London. 
Woodward, A. (2003) 'European Gender Mainstreaming: Promises and Pitfalls of Transformative Policy', The Review of Policy Research, 20 (1): 65-88.

\footnotetext{
${ }^{i}$ In 1995 the European Court of Justice in the case Kalanke vs. Freie Hansestadt Bremen that a German state law guaranteeing women automatic priority over men in the labour market was contrary to the European Equal Treatment Directive that prohibits sex-based discrimination.
} 